\title{
Functional polymorphisms in the VEGF gene are not associated with age-related macular degeneration in a Mexican population
}

\section{Polimorfismos del gen VEGF no están asociados con degeneración macular relacionada con la edad en población mexicana}

\author{
Ramses Rosales-Diaz' ${ }^{1}$ Arturo Santos-Garcia ${ }^{2,3}$, Jose Navarro-Partida ${ }^{2,3}$, Veronica Benites-Godinez ${ }^{4}$, \\ Daniel Díaz-Palomera ${ }^{5}$ and Adolfo Daniel Rodríguez-Carrizalez ${ }^{6 *}$ \\ ${ }^{1}$ Unidad Académica de Medicina, Universidad Autónoma de Nayarit, Tepic, Nay; ${ }^{2}$ Tecnológico de Monterrey, Escuela de Medicina y Ciencias de \\ la Salud, Zapopan, Jal. ${ }^{3}$ Centro de Retina Médica y Quirúrgica, Centro Médico Puerta de Hierro. Zapopan, Jal; ${ }^{4}$ Instituto Mexicano del Seguro \\ Social, Nayarit; ${ }^{5}$ Instituto de Biología Molecular en Medicina y Terapia Génica, Universidad de Guadalajara, Guadalajara, Jal. ${ }^{6}$ Instituto de Terapéutica \\ Experimental y Clínica, Departamento de Fisiología, Centro Universitario de Ciencias de la Salud, Universidad de Guadalajara, Guadalajara, Jal. \\ México
}

\begin{abstract}
Introduction: The wet form of age-related macular degeneration (WAMD) is related to the expression of vascular endothelial growth factor (VEGF). Several single nucleotide polymorphisms (SNPS) in the VEGF gene are associated with different expression patterns of this cytokine (functional polymorphisms). In this study, we considered 4 SNPs that are located in the promoter region (rs699947 A/C, rs833061 C/T, rs1005230 C/T and rs1570360 A/G) and two in the 5' untranslated region (rs2010963 C/G and rs25648 C/T) that have an effect on transcriptional regulation. Objective: To associate functional SNPS with WAMD in a Mexican population. Methods: Through allelic discrimination assays, consisting in polymerase chain reactions $(P C R)$ with Taqman ${ }^{\circledR}$ probes, the polymorphisms were genotyped. Genotype frequencies were compared using all inheritance models. Results: SNPs were genotyped in 105 patients diagnosed with WAMD (61 women and 44 men, mean age $74.28 \pm 8.32$ years), and in 102 healthy control subjects (61 women and 41 men, mean age $67.41 \pm 5.78$ years). Genotypes in both groups were in Hardy-Weinberg equilibrium. In all SNPs analyzed, the minor allele frequency was statistically significant different between the groups. Genotypes were not statistically significant different between the WAMD and the control groups $(p>0.05)$. Conclusion: No association was observed between the studied SNPs and the presence of WAMD in the analyzed Mexican population. We consider that further analysis in larger samples is necessary to confirm these findings.
\end{abstract}

Key words: Polymorphisms. Age-related macular degeneration. Vascular endothelial growth factor.

\section{Resumen}

Introducción: La degeneración macular relacionada con la edad (DMRE) exudativa está asociada con la expresión del factor de crecimiento vascular endotelial (VEGF). Varios polimorfismos de un solo nucleótido (SNP) en el gen VEGF están asociados con diferentes patrones de expresión de esta citocina (polimorfismos funcionales). En este estudio, consideramos 4 SNP que

\section{Correspondence:}

*Adolfo Daniel Rodríguez-Carrizalez

Instituto de Terapéutica Experimental y Clínica,

Col. Independencia 44340,

Date of reception: 23-08-2019

Date of acceptance: 17-02-2020

E-mail: adolfo.rodriguez@academicos.udg.mx DOI: 10.24875/RMOE.M20000106
Available online: 04-05-2020 Rev Mex Oftalmol (Eng). 2020;94(3):110-115

www.rmo.com.mx 2604-1731/○ 2020 Sociedad Mexicana de Oftalmología. Published by Permanyer. This is an open access article under the CC BY-NC-ND license (http://creativecommons.org/licenses/by-nc-nd/4.0/). 
están ubicados en la región promotora (rs699947 A/C, rs833061 C/T, rs1005230 C/T y rs1570360 A/G) y dos en la región 5' no traducida (rs2010963 C/G y rs25648 C/T) que tienen efecto sobre la regulación de la transcripción. Objetivo: Asociar SNP funcionales con la DMRE exudativa en población mexicana. Métodos: A través de reacción en cadena de la polimerasa con ensayos de discriminación alélica con sondas Taqman ${ }^{\circledR}$, los polimorfismos fueron genotipados. Las frecuencias genotípicas se compararon utilizando todos los modelos de herencia. Resultados: Los SNP fueron genotipados en 105 pacientes diagnosticados con DMRE exudativa (61 mujeres y 44 hombres, edad promedio $74.28 \pm 8.32$ años) y en 102 sujetos control sanos (61 mujeres y 41 hombres, edad promedio $67.41 \pm 5.78$ años). Los genotipos en ambos grupos estaban en el equilibrio de Hardy-Weinberg. En cualquiera de los SNP analizados, la frecuencia de alelos menores fue diferente entre los grupos, con significación estadística. Los genotipos no mostraron diferencias estadísticamente significativas entre la DMRE exudativa y los grupos control $(p>0.05)$. Conclusión: No se encontró asociación entre los SNP estudiados y la presencia de DMRE exudativa en la población mexicana analizada. Consideramos necesario un análisis adicional en muestras más grandes para confirmar estos hallazgos.

Palabras clave: Polimorfismos. Degeneración macular asociada con la edad. Factor de crecimiento vascular endotelial.

\section{Introduction}

Age-related macular degeneration (AMD) is a neurodegenerative disease of the retina, characterized by a progressive decrease of central vision. It represents the leading cause of vision loss in people over 50 years old ${ }^{1}$.

AMD can present in two well-differentiated clinical forms; each, with different pathological qualities. Atrophic, non-exudative AMD is characterized by a progressive atrophy of the retinal pigment epithelium, photoreceptors, and choriocapillaris. On the contrary, in neovascular, exudative or wet form of AMD (WAMD), choroidal neovascularization (CNV) and subretinal neovascular fibrous tissue has developed due to leakage of fluids and lipids within the retina ${ }^{1,2}$.

$\mathrm{AMD}$ is a multifactorial disease; some of the risk factors associated are age, smoking, exposure to sunlight, diet and genetics. The important role that genetic factors play in the pathophysiology of AMD has been demonstrated by different studies ${ }^{3-5}$. There are several genes involved in different biological pathways, such as the immune and complement pathways (CFH, C2/CFB, $\mathrm{CFI}, \mathrm{C3}$, and C9), lipids transport (APOE, LIPC, CETP and BAIAP2L2), extracellular matrix remodeling (COL8A1, COL8A1, COL10A1, TIMP3, ADAMTS9, TGFBR1, HTRA1, and B3GALTL) and angiogenesis (VEGFA, TGFBR1, and ADAMTS9) 6 . Vascular endothelial growth factor (VEGF) is one of the main cytokines involved in the angiogenesis and CNV pathways, present in WAMD.

The cytokine family of VEGF includes VEGF-A, VEGF-B, VEGF-C, VEGF-D, VEGF-E, and placental growth factor (PGF). These factors are critical for the development and maintenance of normal vascular function, directly affecting the proliferation, survival, and migration of endothelial cells. Respectively, each VEGF isoform may have an angiogenic or anti-angiogenic effect. Regarding the angiogenic effect, VEGF-A is the main mediator. Angiogenesis occurs as a result of several stimuli, such as tissue hypoxia, shear stress, and the development of tumoral cells; consequently, improving blood perfusion ${ }^{7-9}$. More recently, in different populations, the association between certain VEGF polymorphisms, and their role as genetic risk factors in WAMD has been previously observed ${ }^{10,11}$. However, results are controversial. One example is the polymorphism with rs833061 located in the promoter region of the VEGF gene, which has been related to greater promoter activity ${ }^{12,13}$ and an increment in WAMD in Chinese Tujia group and Polish population ${ }^{14}$. On the contrary, other studies have not found a correlation with the susceptibility to WAMD in the Taiwan Chinese, Han Chinese and Spanish populations s5-17. $^{15}$.

There are more than 100 single nucleotide polymorphisms (SNPS) identified in the VEGF gene to date (http://www.ncbi.nlm.nih.gov/SNP). Many of them are associated with different expression patterns of this cytokine and they are commonly called functional polymorphisms. In this study, we considered 4 functional SNPs in the VEGF gene that are located in the promoter region (rs699947 A/C, rs833061 C/T, rs1005230 C/T and $\mathrm{rs} 1570360 \mathrm{~A} / \mathrm{G}$ ) and two in the 5' untranslated region (rs2010963 C/G and rs25648 C/T) that have been positively correlated with the transcription of the VEGF gene ${ }^{15-22}$. All of these, with the purpose of establishing a genetic pattern of a Mexican population, which may determine the risk for developing exudative WAMD.

\section{Patients and methods}

\section{Patients}

A total 105 patients who were not related (44 men and 61 women; mean age $74.28 \pm 8.32$ years) were included in the case group. They were diagnosed with WAMD at 
Centro Medico Nacional de Occidente, Instituto Mexicano del Seguro Social, Jalisco, Mexico. The criteria for classifying a patient as a case were ophthalmological examination with data of WAMD; sub-retinal fluid, hemorrhages and lipids associated with a macular gray-brown membrane and CNV by retinal fluorescence angiography. Patients were excluded if they had a diagnosis of CNV secondary to trauma or not associated with age. A total of 41 men and 61 women with a mean age of $67.41 \pm$ 5.78 years were included in the control group. The inclusion criteria for the control group were ophthalmological examination without data suggestive of WAMD and age older than 60 years. The study was approved by the ethics committee of the Centro de Retina Médica y Quirúrgica S.C., and complied with the guidelines of the Declaration of Helsinki. Informed consent was obtained for genetic screening for all control and case subjects.

\section{Sample preparation and genotyping}

Target SNPs in the VEGF-A gene were selected based on their strong association with WAMD. The selected SNPs are located in non-coding and promoter regions of the VEGF-A gene (locus 6p21.1); rs2010963 C/G, rs25648 C/T within the $5^{\prime}$ untranslated region and rs833061 C/T, rs699947 A/C, rs1570360 A/G, rs $1005230 \mathrm{C} / \mathrm{T}$, within the promoter region. The positions of these polymorphisms are 5398, 6025, 4534, 3437, 4878 and 3544 respectively (Assembly; GRCh38.p7, RefSeqGene, NG_008732.1; Gene ID, VEGFA 7422).

Genomic DNA was extracted from frozen total blood and purified with the Qiagen QIAamp DNA Blood Kit (Qiagen, Valencia, California, USA). Genotyping of target SNPs was performed using validated $\operatorname{TaqMan}^{\circledR}$ SNP genotyping assays (TaqMan: Applied Biosystems, Inc. [ABI], Foster City, CA). The SNPs were amplified by real time polymerase chain reaction (PCR) using $0.5 \mu \mathrm{M}$ primers and TaqMan Genotyping Master Mix (TaqMan: Applied Biosystems, Inc. [ABI], Foster City, $\mathrm{CA}$ ) with $30 \mathrm{ng}$ of template DNA in the amplification mixture $(25 \mu \mathrm{L})$. The fluorescence signal of the probe was detected with the StepOnePlus ${ }^{\mathrm{TM}}$ Real-Time PCR System (Applied Biosystems, Inc. [ABI], Carlsbad, CA).

\section{Sample size calculation and statistical analyses}

Prevalence of age related macular degeneration increases with age and it is influenced by ethnicity. The prevalence can be as low as $2.5 \%$ in white adults over 50 years old up to $14 \%$ in white adults over 80 years
Table 1. Frequency of SNPs alleles in the AMD and control groups

\begin{tabular}{|c|c|c|c|c|c|}
\hline \multirow[t]{2}{*}{ SNP/alleles } & & AMD & Control & \multirow[t]{2}{*}{ OR (CI 95\%) } & \multirow[t]{2}{*}{ p } \\
\hline & & $n=210$ & $\mathrm{n}=\mathbf{2 0 4}$ & & \\
\hline rs1570360 (E) & $A / G$ & $\begin{array}{c}49 \\
(0.23)\end{array}$ & $\begin{array}{c}45 \\
(0.22)\end{array}$ & $\begin{array}{c}1.0754 \\
(0.678-1.703)\end{array}$ & 0.75 \\
\hline rs833061 (H) & $\mathrm{C} / \mathrm{T}$ & $\begin{array}{c}90 \\
(0.43)\end{array}$ & $\begin{array}{c}84 \\
(0.41)\end{array}$ & $\begin{array}{c}1.0714 \\
(0.725-1.583)\end{array}$ & 0.72 \\
\hline rs2010963 (F) & $C / G$ & $\begin{array}{c}82 \\
(0.39)\end{array}$ & $\begin{array}{c}78 \\
(0.38)\end{array}$ & $\begin{array}{c}1.0349 \\
(0.696-1.537)\end{array}$ & 0.86 \\
\hline rs25648 (K) & $\mathrm{C} / \mathrm{T}$ & $\begin{array}{c}176 \\
(0.84)\end{array}$ & $\begin{array}{c}164 \\
(0.8)\end{array}$ & $\begin{array}{c}1.2626 \\
(0.762-2.090)\end{array}$ & 0.36 \\
\hline rs699947 (I) & $A / C$ & $\begin{array}{c}85 \\
(0.4)\end{array}$ & $\begin{array}{c}86 \\
(0.42)\end{array}$ & $\begin{array}{c}0.933 \\
(0.630-1.379)\end{array}$ & 0.72 \\
\hline rs1005230 (J) & $\mathrm{C} / \mathrm{T}$ & $\begin{array}{c}125 \\
(0.6)\end{array}$ & $\begin{array}{c}121 \\
(0.59)\end{array}$ & $\begin{array}{c}1.0088 \\
(0.681-1.493)\end{array}$ & 1 \\
\hline
\end{tabular}

Source: RefSeqGene, NG_008732.1; Gene ID, VEGFA (7422), https://www.ncbi.nlm. nih.gov/refseg/rsg/.

$A M D$, age-related macular degeneration; IC, confidence interval; $O R$, odds ratio; SNP, single nucleotide polymorphism.

old. Therefore, considering a dominant genetic model and assuming $5 \%$ of minor allele frequency, $5 \%$ of disease prevalence, a 1:1 case-control ratio, and $5 \%$ of type I error and an expected OR of 2 for single marker analyses, the minimum number of cases required to achieve a power of $80 \%$ was 90 . IBM SPSS statistics software (version 21.0, SPSS, Inc., Chicago, IL) was used for statistical analyses. The Hardy-Weinberg equilibrium was analyzed using gene frequencies obtained by simple gene counting and the $\chi^{2}$ test with Yates' correction for comparing observed and expected values. Differences in the genotype frequencies among the cases and controls were tested by Fisher exact test or $\chi^{2}$. The inferred haplotypes and LD (linkage disequilibrium) quantified between the biallelic loci, were estimated using the SNPStats online software (http:// bioinfo.iconcologia.net/SNPstats). The significance of an association was determined by contingency table analysis using $\chi^{2}$ or Fisher exact tests. Significance was defined as a $p$ value less than 0.05 .

\section{Results}

\section{Allele and genotypes frequencies}

All the SNPs were genotyped in all subjects; the frequencies were found in Hardy-Weinberg equilibrium in both groups. The difference between the allele frequencies was not statistically significant in any of the SNPS analyzed (Table 1). 
Table 2. Frequency of genotypes in VEGF single nucleotide polymorphisms

\begin{tabular}{|c|c|c|c|c|c|c|c|}
\hline \multirow[t]{2}{*}{ Gene position } & \multirow[t]{2}{*}{ SNP } & \multirow[t]{2}{*}{ SNP position } & \multirow[t]{2}{*}{ SNP location } & \multirow[t]{2}{*}{ Genotypes } & AMD & Control & \multirow[t]{2}{*}{ p } \\
\hline & & & & & $n=105$ & $n=102$ & \\
\hline \multirow[t]{6}{*}{$6 p 21.1$} & rs833061 & 4534 & promoter region & $\begin{array}{l}\mathrm{C} / \mathrm{T} \\
\mathrm{C} / \mathrm{C} \\
\mathrm{T} / \mathrm{T}\end{array}$ & $\begin{array}{l}54(0.51) \\
18(0.17) \\
33(0.31)\end{array}$ & $\begin{array}{l}48(0.47) \\
18(0.18) \\
36(0.35)\end{array}$ & 0.8 \\
\hline & rs699947 & 3437 & promoter region & $\begin{array}{l}\mathrm{A} / \mathrm{C} \\
\mathrm{A} / \mathrm{A} \\
\mathrm{C} / \mathrm{C}\end{array}$ & $\begin{array}{l}55(0.52) \\
15(0.14) \\
35(0.33)\end{array}$ & $\begin{array}{c}46(0.45) \\
20(0.2) \\
36(0.35)\end{array}$ & 0.47 \\
\hline & rs 1005230 & 3544 & promoter region & $\begin{array}{l}\mathrm{C} / \mathrm{T} \\
\mathrm{C} / \mathrm{C} \\
\mathrm{T} / \mathrm{T}\end{array}$ & $\begin{array}{l}55(0.52) \\
35(0.33) \\
15(0.14)\end{array}$ & $\begin{array}{l}47(0.46) \\
37(0.36) \\
18(0.18)\end{array}$ & 0.63 \\
\hline & rs 1570360 & 4878 & promoter region & $\begin{array}{l}A / G \\
A / A \\
G / G\end{array}$ & $\begin{array}{c}37(0.35) \\
6(0.06) \\
62(0.59)\end{array}$ & $\begin{array}{c}37(0.36) \\
4(0.04) \\
61(0.6)\end{array}$ & 0.83 \\
\hline & rs2010963 & 5398 & UTR 5' & $\begin{array}{l}\mathrm{C} / \mathrm{G} \\
\mathrm{C} / \mathrm{C} \\
\mathrm{G} / \mathrm{G}\end{array}$ & $\begin{array}{l}50(0.48) \\
16(0.15) \\
39(0.37)\end{array}$ & $\begin{array}{l}48(0.47) \\
15(0.15) \\
39(0.38)\end{array}$ & 0.98 \\
\hline & rs 25648 & 6025 & UTR 5' & $\begin{array}{l}\mathrm{C} / \mathrm{T} \\
\mathrm{C} / \mathrm{C} \\
\mathrm{T} / \mathrm{T}\end{array}$ & $\begin{array}{c}24(0.23) \\
76(0.72) \\
5(0.05)\end{array}$ & $\begin{array}{c}36(0.35) \\
64(0.63) \\
2(0.02)\end{array}$ & 0.096 \\
\hline
\end{tabular}

Source: RefSeqGene, NG_008732.1; Gene ID, VEGFA (7422), https://www.ncbi.nlm.nih.gov/refseq/rsg/.

UTR, untranslated region; SNP, single nucleotide polymorphism; AMD, age-related macular degeneration; VEGF, vascular endothelial growth factor.

Table 3. Haplotype frequencies of Tag SNPs in the VEGF gene between AMD and control subjects

\begin{tabular}{|c|c|c|c|c|c|c|c|c|c|c|}
\hline \multicolumn{6}{|c|}{ Tag SNPs } & \multirow[t]{2}{*}{ Total } & \multirow[t]{2}{*}{ AMD } & \multirow[t]{2}{*}{ Control } & \multirow[t]{2}{*}{ OR (CI 95\%) } & \multirow[t]{2}{*}{ p } \\
\hline rs1570360 & rs2010963 & rs833061 & rs699947 & rs1005230 & rs 25648 & & & & & \\
\hline G & C & $\mathrm{T}$ & C & C & C & 0.369 & 0.3905 & 0.3701 & 1 & - \\
\hline A & G & C & $A$ & T & C & 0.2263 & 0.2227 & 0.2156 & $0.97(0.57-1.64)$ & 0.91 \\
\hline G & G & $\mathrm{T}$ & C & C & C & 0.187 & 0.171 & 0.1933 & $1.18(0.67-2.07)$ & 0.58 \\
\hline G & G & C & A & $\mathrm{T}$ & $\mathrm{T}$ & 0.1543 & 0.1375 & 0.1713 & $1.20(0.67-2.13)$ & 0.54 \\
\hline G & G & C & $A$ & $\mathrm{~T}$ & C & 0.0195 & 0.034 & 0.0048 & $0.16(0.02-1.43)$ & 0.1 \\
\hline G & G & C & C & C & C & 0.0121 & 0.02 & 0.0049 & $0.28(0.02-3.25)$ & 0.31 \\
\hline
\end{tabular}

SNP, single nucleotide polymorphism; AMD, age-related macular degeneration; VEGF, vascular endothelial growth factor.

Genotyped frequencies were compared by applying the co-dominant, dominant and recessive models. None of the inheritance models showed a statistically significant association in the WAMD group compared to the control group (Table 2).

\section{Haplotype analysis}

All the VEGF SNPs were located in 1 haplotype block, and the magnitude of the LD between biallelic loci was very high, with a pairwise $D^{\prime}=0.8205$. The haplotype frequencies of the studied SNPs are shown in Table 3. Tag SNPs were not statistically significant.

\section{Discussion}

The human VEGF-A gene is located on the chromosomal region $6 \mathrm{p} 21.1$. Several isoforms are generated by alternative splicing producing proteins of 121, 145, 162, 165, 183, 189, and 206 amino acids with differences in its properties. Each tissue expresses different proportions of the VEGF isoforms depending on their 
specifics needs. The VEGF 165 isoform is the one most frequently observed in the human eye $\mathrm{e}^{23-25}$.

Its role in choroidal neovascularization has been clearly showed $d^{9}$. For example, it has been demonstrated an increase of VEGF expression in eye animal models ${ }^{26-29}$.

Several genetics factors related to VEGF expression control are being investigated for their role in the pathogenesis of WAMD; it was observed that MEF2 (Myocyte enhancer factor 2) activate transcriptional expression of VEGF trough DII4 (Delta-like ligand 4) during angiogenesis ${ }^{30}$. Another study showed that a transcriptional coactivator (PGC-1 $\alpha$ ) is able to up-regulate the expression of VEGFA in the retina ${ }^{31}$. However, the molecular links between proangiogenic signals and the pathophysiology of WAMD are limited.

Earlier studies about the association of VEGF-A SNPs with WAMD showed contrasting results in different populations. The polymorphism with rs833061 located in the promoter region of the VEGF gene, which has been related to a greater promoter activity ${ }^{12,13}$ has been analyzed in previous studies that suggested that WAMD has a weak correlation with this SNP in a Chinese Tujia group and in a Polish population ${ }^{14}$. On the contrary, other studies have not found a correlation with the susceptibility to WAMD in Taiwan Chinese, Han Chinese and Spanish populations ${ }^{15-17}$.

The polymorphism rs699947 located in the promoter region of the VEGF gene, has shown a correlation with a higher production of $\mathrm{VEGF}^{18}$. In a Korean cohort study, carrying the major allele was associated with a good visual response to anti-VEGF therapy due to lower VEGF production ${ }^{32}$. On one hand, several studies have shown no association between SNPs and WAMD in Netherlands, Taiwan Chinese, Finland, Japanese, Spanish and Turkish populations (15, 17, 19-22). On the other hand, in a population of Pakistan, a risk association between the polymorphism and morbidity of WAMD has been demonstrated ${ }^{33}$. However, our data are consistent with the findings reported in most populations.

Although rs2010963 is a functional polymorphism associated with elevated serum and vitreous levels of VEGF-A in the human retina ${ }^{34,35}$, no pharmacogenetic association has been demonstrated with the response to anti-VEGF agents in different populations ${ }^{36,37}$. In addition, the association between this polymorphism and WAMD has not been clearly demonstrated, there are discrepancies between populations such as Chinese, Japanese and Taiwanese where there is no significant association, and Polish where there is one 14-16,21. $^{10}$
Polymorphism rs25648 has been studied in pathologies in which angiogenesis plays an important role, such as bladder cancer, which shows a significant increase in the risk of developing $i^{38}$. However, in this study it was not shown that there is an association with WAMD in our population. In addition, this polymorphism has not been clearly studied in WAMD. In a study that included Caucasian population, no association was observed ${ }^{39}$.

There is consistent information on the correlation of the SNP rs1570360 with vascular diseases such as stroke and hypertension ${ }^{40,41}$ and its activity, with higher VEGF-A production ${ }^{13}$. In our population, as well as in populations from Japan and Netherlands, there is no association between the polymorphism and susceptibility to WAMD ${ }^{19,21}$. Similarly, no association of the rs1005230 polymorphism with WAMD has been observed, nor has it been shown to improve the response to anti-VEGF treatment in patients with WAMD ${ }^{42}$.

So far, there is still contrasting information about the association of VEGF gene polymorphisms with WAMD in different populations. Although some studies have found a risk association, in this Mexican population we did not observe a correlation with any of the studied SNPs. However, this not statistically significant findings could be related to the sample size. In fact, the main limitation of our study is the reduced number of subjects included. Therefore, it is necessary to expand the sample in order to estimate accurately the risk associations.

\section{Conclusion}

No association was found between the studied SNPs and the presence of WAMD in the analyzed Mexican population. These findings are consistent with previous reports that evaluated populations from Netherlands, Taiwan, Finland, Japan, Spanish and Turkey. We consider that further analysis in larger samples are necessary in order to confirm these findings.

\section{Ethical disclosures}

Protection of human and animal subjects. The authors declare that the procedures followed were in accordance with the regulations of the relevant clinical research ethics committee and with those of the Code of Ethics of the World Medical Association (Declaration of Helsinki). 
Confidentiality of data. The authors declare that they have followed the protocols of their work center on the publication of patient data.

Right to privacy and informed consent. The authors have obtained the written informed consent of the patients or subjects mentioned in the article. The corresponding author is in possession of this document.

\section{Conflicts of interest}

the authors report no conflicts of interest. The authors alone are responsible for the content and writing of this article.

\section{References}

1. Barchitta M, Maugeri A. Association between Vascular Endothelial Growth Factor Polymorphisms and Age-Related Macular Degeneration: An Updated Meta-Analysis. Dis Markers. 2016;2016:8486406.

2. Lim LS, Mitchell P, Seddon JM, Holz FG, Wong TY. Age-related macular degeneration. Lancet. 2012;379(9827):1728-38.

3. Armstrong RA, Mousavi M. Overview of Risk Factors for Age-Related Macular Degeneration (AMD). J Stem Cells. 2015;10(3):171-91.

4. Klein BE, Howard KP, lyengar SK, Sivakumaran TA, Meyers KJ, Cruickshanks KJ, et al. Sunlight exposure, pigmentation, and incident age-related macular degeneration. Invest Ophthalmol Vis Sci. 2014:55(9):5855-61.

5. Nowak JZ. AMD--the retinal disease with an unprecised etiopathogenesis: in search of effective therapeutics. Acta Pol Pharm. 2014;71(6):900-16.

6. Fritsche LG, Fariss RN, Stambolian D, Abecasis GR, Curcio CA, Swaroop A. Age-related macular degeneration: genetics and biology coming together. Annu Rev Genomics Hum Genet. 2014;15:151-71.

7. Vempati P, Popel AS, Mac Gabhann F. Extracellular regulation of VEGF: isoforms, proteolysis, and vascular patterning. Cytokine Growth Factor Rev. 2014;25(1):1-19.

8. Koch S, Claesson-Welsh L. Signal transduction by vascular endothelial growth factor receptors. Cold Spring Harb Perspect Med. 2012; 2(7): $a 006502$

9. Witmer AN, Vrensen GF, Van Noorden CJ, Schlingemann RO. Vascular endothelial growth factors and angiogenesis in eye disease. Prog Retin Eye Res. 2003;22(1):1-29.

10. Liu Y, Hou S, Lang W, Dai D, Wang Z, Ji X, et al. Roles of three common VEGF polymorphisms in the risk of age-related macular degeneration. Genet Test Mol Biomarkers. 2014;18(4):245-52.

11. Gupta D, Gupta V, Singh V, Prakash S, Agrawal S, Chawla S, et al Vascular endothelial growth factor gene polymorphisms and association with age related macular degeneration in Indian patients. Meta Gene. 2016;9:249-53.

12. Stevens A, Soden J, Brenchley PE, Ralph S, Ray DW. Haplotype analysis of the polymorphic human vascular endothelial growth factor gene promoter. Cancer Res. 2003;63(4):812-6.

13. Wu X, Xin Z, Zhang W, Wu J, Chen K, Wang $\mathrm{H}$, et al. Polymorphisms in the VEGFA promoter are associated with susceptibility to hepatocellular carcinoma by altering promoter activity. Int J Cancer. 2013;133(5):1085-93

14. Janik-Papis K, Zaras M, Krzyzanowska A, Wozniak K, Blasiak J, Szaflik J, et al. Association between vascular endothelial growth factor gene polymorphisms and age-related macular degeneration in a Polish population. Exp Mol Pathol. 2009;87(3):234-8.

15. Lin JM, Wan L, Tsai YY, Lin HJ, Tsai Y, Lee CC, et al. Vascular endothelial growth factor gene polymorphisms in age-related macular degeneration. Am J Ophthalmol. 2008;145(6):1045-51.

16. Qu Y, Dai H, Zhou F, Zhang X, Xu X, Zhang X, et al. Vascular endothelial growth factor gene polymorphisms and risk of neovascular age-related macular degeneration in a Chinese cohort. Ophthalmic Res. 2011:45(3):142-8.

17. Cruz-Gonzalez F, Cabrillo Estevez L, Canete Campos C, Sanchez-Jara Sanchez A, Juan Marcos L, Gonzalez-Sarmiento R. The presence of CFH, HTRA1, ARMS2, VEGF-A and VEGF-R and the appearance of age-related macular degeneration sub-types. Arch Soc Esp Oftalmol. 2016;91(4):177-83.

18. Szeto CC, Chow KM, Poon P, Szeto CY, Wong TY, Li PK. Genetic polymorphism of VEGF: Impact on longitudinal change of peritoneal transport and survival of peritoneal dialysis patients. Kidney Int. 2004;65(5):1947-55

19. Boekhoorn SS, Isaacs A, Uitterlinden AG, van Duijn CM, Hofman A, de Jong PT, et al. Polymorphisms in the vascular endothelial growth factor gene and risk of age-related macular degeneration: the Rotterdam Study Ophthalmology. 2008;115(11):1899-903.

20. Immonen I, Seitsonen S, Tommila P, Kangas-Kontio T, Kakko S, Savolainen ER, et al. Vascular endothelial growth factor gene variation and the response to photodynamic therapy in age-related macular degeneration. Ophthalmology. 2010;117(1):103-8.

21. Mori K, Horie-Inoue K, Gehlbach PL, Takita H, Kabasawa S, Kawasaki I, et al. Phenotype and genotype characteristics of age-related macular degeneration in a Japanese population. Ophthalmology. 2010;117(5):928-38.

22. Kepez Yildiz B, Ozdek S, Ergun MA, Ergun S, Yaylacioglu Tuncay F, Elbeg S. CFH Y402H and VEGF Polymorphisms and Anti-VEGF Treatment Response in Exudative Age-Related Macular Degeneration. Ophthalmic Res. 2016;56(3):132-8.

23. Lu Y, Shi Y, Xue C, Yin J, Huang Z. Pooled-analysis of the associations between three polymorphisms in the VEGF gene and age-related macular degeneration. Mol Biol Rep. 2012;39(6):6547-53.

24. Kinnunen K, Yla-Herttuala S. Vascular endothelial growth factors in retinal and choroidal neovascular diseases. Ann Med. 2012;44(1):1-17.

25. Goncalves FT, Cezario SM, Calastri MC, Oliveira CI, Souza DR, Pinhel MA, et al. Influence of VEGF-C936T genetic variant on age-related macular degeneration. Arq Bras Oftalmol. 2015;78(5):290-4.

26. Okamoto N, Tobe T, Hackett SF, Ozaki H, Vinores MA, LaRochelle W, et al. Transgenic mice with increased expression of vascular endothelial growth factor in the retina: a new model of intraretinal and subretinal neovascularization. Am J Pathol. 1997;151(1):281-91.

27. Wong CG, Taban M, Osann K, Ross-Cisneros FN, Bruice TC, Zahn G, et al. Subchoroidal Release of VEGF and bFGF Produces Choroidal Neovascularization in Rabbit. Curr Eye Res. 2017;42(2):237-43.

28. Qiu G, Stewart JM, Sadda S, Freda R, Lee S, Guven D, et al. A new model of experimental subretinal neovascularization in the rabbit. Exp Eye Res. 2006;83(1):141-52.

29. Julien S, Kreppel F, Beck S, Heiduschka P, Brito V, Schnichels S, et al. $A$ reproducible and quantifiable model of choroidal neovascularization induced by VEGF A165 after subretinal adenoviral gene transfer in the rabbit. Mol Vis. 2008:14:1358-72.

30. Sacilotto N, Chouliaras KM, Nikitenko LL, Lu YW, Fritzsche M, Wallace $M D$, et al. MEF2 transcription factors are key regulators of sprouting angiogenesis. Genes Dev. 2016;30(20):2297-309.

31. Saint-Geniez M, Jiang A, Abend S, Liu L, Sweigard H, Connor KM, et al. PGC-1alpha regulates normal and pathological angiogenesis in the retina. Am J Pathol. 2013;182(1):255-65.

32. Park UC, Shin JY, Kim SJ, Shin ES, Lee JE, McCarthy LC, et al. Genetic factors associated with response to intravitreal ranibizumab in Korean patients with neovascular age-related macular degeneration. Retina. 2014;34(2):288-97.

33. Ambreen F, Ismail M, Qureshi IZ. Association of gene polymorphism with serum levels of inflammatory and angiogenic factors in Pakistani patients with age-related macular degeneration. Mol Vis. 2015;21:985-99.

34. Vailati FB, Crispim D, Sortica DA, Souza BM, Brondani LA, Canani LH. The $C$ allele of $-634 \mathrm{G} / \mathrm{C}$ polymorphism in the VEGFA gene is associated with increased VEGFA gene expression in human retinal tissue. Invest Ophthalmol Vis Sci. 2012;53(10):6411-5.

35. Petrovic MG, Korosec P, Kosnik M, Osredkar J, Hawlina M, Peterlin B, et al. Local and genetic determinants of vascular endothelial growth factor expression in advanced proliferative diabetic retinopathy. Mol Vis. 2008;14:1382-7.

36. Hagstrom SA, Ying GS, Pauer GJ, Sturgill-Short GM, Huang J, Maguire MG, et al. VEGFA and VEGFR2 gene polymorphisms and response to anti-vascular endothelial growth factor therapy: comparison of age-related macular degeneration treatments trials (CATT). JAMA Ophthalmol. 2014;132(5):521-7.

37. Habibi I, Kort F, Sfar I, Chebil A, Bouraoui R, Ben Abdallah T, et al. Effect of Risk Alleles in CFH, C3, and VEGFA on the Response to Intravitreal Bevacizumab in Tunisian Patients with Neovascular Age-related Macular Degeneration. Klin Monbl Augenheilkd. 2016;233(4):465-70.

38. Song $Y$, Yang $Y$, Liu L, Liu X. Association between five polymorphisms in vascular endothelial growth factor gene and urinary bladder cancer risk: A systematic review and meta-analysis involving 6671 subjects. Gene. 2019;698:186-97.

39. Fang AM, Lee AY, Kulkarni M, Osborn MP, Brantley MA, Jr. Polymorphisms in the VEGFA and VEGFR-2 genes and neovascular age-related macular degeneration. Mol Vis. 2009;15:2710-9.

40. Malkiewicz A, Slominski B, Skrzypkowska M, Siebert J, Gutknecht P, Mysliwska J. The GA genotype of the $-1154 \mathrm{G} / \mathrm{A}$ (rs1570360) vascular endothelial growth factor (VEGF) is protective against hypertension-related chronic kidney disease incidence. Mol Cell Biochem. 2016;418(1-2):159-65.

41. Yadav BK, Yadav $\mathrm{R}$, Chang $\mathrm{H}$, Choi $\mathrm{K}, \mathrm{Kim}$ JT, Park MS, et al. Genetic Polymorphisms rs699947, rs1570360, and rs3025039 on the VEGF Gene Are Correlated with Extracranial Internal Carotid Artery Stenosis and Ischemic Stroke. Ann Clin Lab Sci. 2017:47(2):144-55.

42. Boltz A, Ruiss M, Jonas JB, Tao Y, Rensch F, Weger M, et al. Role of vascular endothelial growth factor polymorphisms in the treatment success in patients with wet age-related macular degeneration. Ophthalmology. 2012;119(8):1615-20. 